considered as a transient pathway of energy supply. This participation diminishes in weanling animals when the young rat provides itself with a carbohydrate-rich diet.

\section{CONCLUSION}

Amino acids are utilized by newborn animals for energy supply, either directly or after carbohydrate conversion through gluconeogenesis. During the first $2 \mathrm{hr}$ after birth and before gluconeogenesis activation, the energy production from glutamate and alanine is not negligible when compared to glucose oxidation. This finding suggests that glutamate and alanine might be oxidized directly by neonates. On the other hand, leucine and phenylalanine are not metabolized.

In suckling and weanling rats, the relative importance of glutamate and alanine as energetic fuels decreases. Leucine degradative pathway appears in 3-week-old rats, in contrast to phenylalanine metabolism, the oxidative process remains of minor importance compared with its incorporation rate into macromolecules. This result may be interesting in regard to a human metabolic disease: phenylketonuria.

\section{REFERENCES AND NOTES}

1. Adam, P. A. J.: Control of glucose metabolism in the human fetus and newborn infant. Advan. Metab. Disord., 5: 183 (1971).

2. Baerlocher, K. E.: Developmental aspects of aminoacid transport. In: Inborn Errors of Metabolism (Academic Press, New York, 1973).

3. Ballard, F. J.: The development of gluconeogenesis in rat liver. Biochem. J., 124: 265 (1971).

4. Beatty, C. H., Curtis, S., Young, M. K., and Bocek, R. M.: Oxidation of aminoacids by red and white muscle fiber groups. Amer. J. Physiol., 227: 268 (1974).

5. Buse, M. G., Biggers, J. F., Friderici, K. H., and Buse, J. F.: Oxidation of branched chain aminoacids by isolated hearts and diaphragms of the rat. $J$. Biol. Chem., 247: 8085 (1972).

6. Girard, J. R., Cuendet, G. S., Marliss, E. B., Kervran, A., Rieutort, M., and Assan, R.: Fuels, hormones and liver metabolism at term and during the early postnatal period in the rat. J. Clin. Invest., 52: 3190 (1973).

7. Girard, J. R., Guillet, I., Marty, J., and Marliss, E. B.: Plasma amino acid levels and development of hepatic gluconeogenesis in the newborn rat.
Amer. J. Physiol, 229: 466 (1975)

8. Goldberg, A. L., and Odessey, R.: Oxidation of aminoacids by diaphragms from fed and fasted rats. Amer. J. Physiol., 223: 1384 (1972).

9. Gresham, E. L., James, E. J., Raye, J. R., Battaglia, F. C., Makowski, E. L., and Meschia, G.: Production and excretion of urea by the fetal lamb. Pediatrics, 50: 372 (1972).

10. McFarlane, I. G., and Von Holt, C.: Metabolism of aminoacids in protein caloric deficient rats. Biochem. J., 111: 557 (1969).

11. McGee, M. M., Greengard, O., and Knox, W. E.: The quantitative determination of phenylalanine hydroxylase in rat tissues. Biochem. J., 127: 669 (1972).

12. McGee, M. M., Greengard, O., and Knox, W. E.: Liver phenylalanine hydroxylase activity in relation to blood concentration of tyrosine and phenylalanine in the rat. Biochem. J., 127: 675 (1972).

13. Manchester, K. L., and Krahl, M. E.: Effect of insulin on the incorporation of ${ }^{14} \mathrm{C}$ from ${ }^{14} \mathrm{C}$ labeled carboxylic acids and bicarbonate into the protein of isolated rat diaphragm. J. Biol. Chem., 234: 2938 (1959).

14. Marsac, C., Saudubray, J. M., Moncion, A., and Leroux, J. P.: Development of gluconeogenic enzymes in the liver of human newborns. Biol. Neonate, 28: 317 (1976).

15. Odessey, R., and Goldberg, A. L.: Oxidation of leucine by rat skeletal muscle. Amer. J. Physiol., 223: 1376 (1972).

16. Philippidis, H., Hanson, R. W., Reshef, L., Hopgood, M. F., and Ballard, F. J.: The initial synthesis of proteins during development. Biochem. J., 126: 1127 (1972)

17. Snell, K.: Gluconeogenesis in the neonatal rat: The metabolism and disposition of alanine during postnatal development. In: F. A. Hommes and C. J. Van Den Berg: Normal and Pathological Development of Energy Metabolism (Academic Press, New York, 1975)

18. Szabo, A. J., and Grimaldi, R. D.: The metabolism of the placenta. Advan. Metab. Disord., 4: 185 (1970).

19. Trayhurn, P., and Van Heyningen, R.: The metabolism of aminoacids in the bovine lens. Biochem. J., 136: 67 (1973).

20. Wagle, S. R., and Ashmore, J.: Interrelationships between amino acid metabolism and carbohydrate formation in insulin deficiency. J. Biol. Chem., 236: 2868 (1961).

21. White, P. K., and Miller, S. A.: Utilization of dietary amino acids for energy production in neonatal rat liver. Pediat. Res., 10: 158 (1976).

22. Yeung, D., and Oliver, I. T.: Gluconeogenesis from aminoacids in neonatal rat liver. Biochem. J., 103: 744 (1967).

23. The authors thank Mr. J. P. Flinois for his skillful technical assistance.

24. Requests for reprints should be addressed to: T. Cresteil, Laboratoire de biochimic. INSERM U-75, CHU Necker-Enfants Malades 156 rue de Vaugirard, 75730-Paris, Cedex 15 (France).

25. Received for publication July $29,1976$.

26. Accepted for publication October 8, 1976
Lecithin

lung

myristic acid neonate

phosphatidyl dimethylethanolamine

phospholipids

\title{
Fatty Acids of Phospholipids in Human Neonatal Lung Surfactant
}

\author{
CHRISTINE E. PARKINSON(32) AND DAVID R. HARVEY \\ Institute of Obstetrics and Gynaecology, Queen Charlotte's Hospital for Women, London, England
}

J. PRYSE-DAVIES

Queen Charlotte's Hospital for Women, London, England

\section{Summary}

The fatty acid chains of lecithin, phosphatidyl ethanolamine (PE), and phosphatidyl dimethylethanolamine (PDME) in human neonatal alveolar washes were analyzed. Both $\alpha$ - and $\beta$ palmitic acid increased with gestational age on all phospholipids analyzed. No evidence for high concentrations of myristic acid was found on any phospholipid.

Babies who were stillborn or who had died of hyaline mem- brane disease (HMD) had lower proportions of $\beta$-lecithin palmitic acid when compared with babies who breathed normally before death. In the HMD group these levels were significantly lower.

\section{Speculation}

The fatty acid chains of the phospholipids in lung surfactant probably influence the degree of surface activity of the phospho. 
lipids and play an important role in the prevention of atelectasis. The physiologically optimum length for the chains of both lecithin and phosphatidyl ethanolamine (that is, the length most efficient in reducing surface tension in the lung) is 16 fully saturated carbon atoms (palmitic acid); future research should aim at stimulating the synthesis of these specific phospholipids in babies who have the respiratory distress syndrome.

Hyaline membrane disease of the newborn, which is known as the idiopathic respiratory distress syndrome (RDS) during life, is still a major cause of death in preterm babies (7). A deficiency of pulmonary surfactant lining the alveoli has been associated with HMD $(3,25)$ and it has also been shown $(1,5)$ that babies who die of HMD have decreased amounts of lung lecithin.

Lung surfactant reduces surface tension in the alveoli and this prevents alveolar collapse. The surfactant contains large quantities of phospholipids, especially dipalmitoyl lecithin $(4,6,8,11$, $14,24)$, which are highly surface active. The chemical formulas of lecithin and phosphatidyl ethanolamine are shown in Figure 1.

Increasing amounts of dipalmitoyl lecithin and other phospholipids appear in fetal lung surfactant with advancing gestation (8). Recently there has been great interest in identifying these phospholipids, specifying their fatty acid chains, and tracing their biosynthetic pathways, since this knowledge may help in the management or prevention of hyaline membrane disease.

Kennedy and Weiss (20) first described the major biosynthetic pathways for lecithin (Fig. 2). Pathway 1 is the phosphorylation of $\alpha$-glycerophosphate by CDP-choline. Pathway 2 is the threestep methylation of PE with $S$-adenosyl methionine acting as the methyl donor. An intermediary compound in this reaction is PDME. Pathway 3, the acylation of lysolecithin by pulmonary macrophages, has also recently been described $(9,17)$.

Enzymic studies have demonstrated that pathway 1 is responsible for $97 \%$ of lecithin production in the fetus. These have been reviewed by Farrell and Avery (10), who felt that the majority of the current evidence points to the fact that there is little activity of pathway 2 in the human fetal lung.

In biochemical studies, the fatty acid chains attached to the $\alpha$ and $\beta$-carbons of the surfactant phospholipids are analyzed and
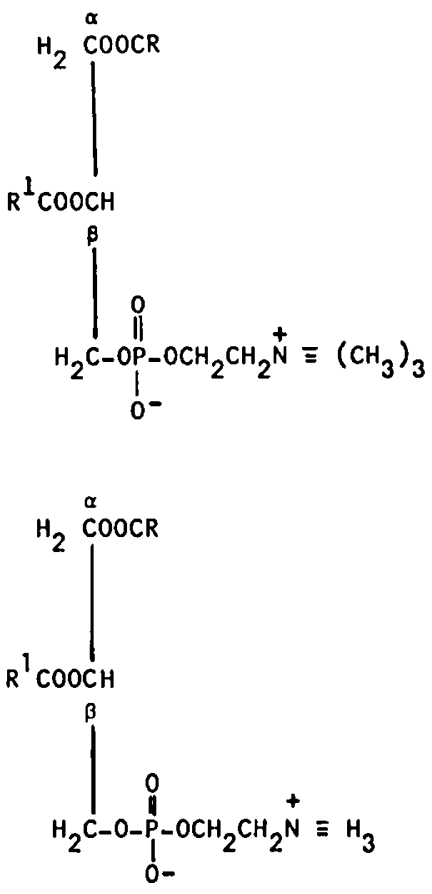

Fig. 1. Chemical formulas of lecithin or phosphatidyl choline (top) and phosphatidyl ethanolamine (bottom). $\mathrm{R}$ and $\mathrm{R}^{1}$ are fatty acid residuals.

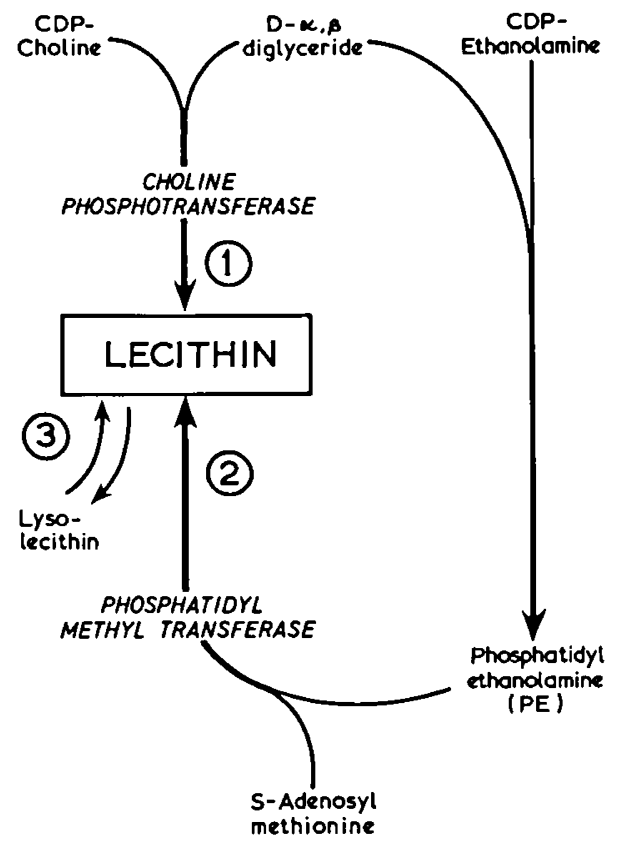

Fig. 2. Main pathways for the biosynthesis of lecithin.

used as indicators of the biosynthetic pathways producing their formation (Fig. 2). In the first of these studies in 1967, Gluck and coworkers (15) confirmed that pathway 1 was the major biosynthetic pathway in the fetal rabbit lung. In a later, similar study (13), they found that myristic acid was the most prominent fatty acid on the $\beta$-carbon of PDME from alveolar wash $(60 \%$ myristic). When large amounts of $\beta$-lecithin myristic acid were found in the pharyngeal aspirates of newborn babies (12), this was taken as indicating that pathway 2 was active; the myristic acid was assumed to have originated from PDME.

There have therefore been conflicting results between enzymic and biochemical studies regarding the most important pathway in the fetus and neonate. This study was carried out to confirm Gluck's original biochemical studies in the human neonatal lung. In particular, it was to seek evidence for large quantities of myristic acid in pulmonary lecithin and PDME.

\section{METHODS}

\section{CLINICAL}

The left lung was removed at postmortem examination from 23 newborn infants (Table 1). Six infants had died from hyaline membrane disease (HMD), confirmed by histologic examination of the right lung.

\section{LUNG WASH PROCEDURE}

When removing the lungs, care was taken to keep a section of the pulmonary artery, bronchus, and trachea intact. The pulmonary artery was cannulated and $0.9 \%$ saline solution was flushed gently through the vascular system until the fluid draining from the pulmonary vein was free of blood. A tube was then inserted through the trachea into the bronchus and tied in position. Small portions of $0.9 \%$ saline were injected into the lung via the tracheal tube and the washings were collected and pooled. Phospholipids were extracted from these washings using the following procedure.

\section{EXTRACTION AND SEPARATION}

Duplicate 2-ml portions of the alveolar washes were extracted into chloroform-methanol $(2: 1)(29)$. The extracted lipids were dried and concentrated in the bottom of a conical tube. These 
tubes were cooled in ice and ice-cold acetone added dropwise to the extract to precipitate the surface-active fraction (13). After precipitation was complete, the acetone was decanted into another tube. The process was then repeated and the acetonesoluble fractions were pooled and evaporated. The precipitates were also dried under nitrogen. Phospholipids in both acetonesoluble and acetone-precipitated fractions were separated by thin layer chromotography and visualized in iodine vapor. Lecithin, PDME, and PE were scraped from the thin layer plates and eluted into chloroform-methanol $(2: 1)$. These extracts were used for: ( 1 ) separation and methylation of the $\beta$-fatty acid chains by incubation with the enzyme, phospholipase $A$, found in the venom of the snake, Naja naja $(17,30)$; (2) separation and methylation of both fatty acids chains by alkaline hydrolysis by a method modified from Warren et al. (26).

\section{GAS CHROMATOGRAPHY}

The fatty acid methyl ester residues were dissolved in $20 \mu \mathrm{l}$ ethyl acetate and 3 - $\mu$ l portions were injected into the column.

\section{CONDITIONS FOR ANALYSIS}

The apparatus used was a Perkin-Elmer F11 gas chromatograph (FID) with a 6 foot glass column packed with $15 \%$ diethylene glycol succinate (DEGS) on 80/100 Chromosorb WAW. The carrier gas was nitrogen at a flow rate of $25 \mathrm{ml} / \mathrm{min}$. The isothermal temperature was $180^{\circ}(31)$.

Fatty acid methyl esters between 14 and 22 carbon chain length were identified and expressed as percentages of each other, thus giving proportions rather than actual concentrations. Twelve possible sets of results were obtained for each lung wash: $\alpha$ - and $\beta$-chains for both the acetone-soluble and acetone-precipitated fractions of lecithin, PDME, and PE.

\section{RESULTS}

\section{LECITHIN}

The results from the 17 non-HMD cases for acetone-precipitated lecithin are shown in Table 2. There was an increase in

Table 1. Clinical details of infants whose lungs were used in study ${ }^{1}$

\begin{tabular}{|c|c|c|c|}
\hline Groups & No. & Cause of death & $\begin{array}{l}\text { Survival } \\
\text { time, hr }\end{array}$ \\
\hline $\begin{array}{l}\text { Stillbirths } \begin{array}{r}(22-26 \\
\text { weeks of gestation) }\end{array}\end{array}$ & 5 & Extreme prematurity & Nil \\
\hline $\begin{array}{l}\text { Stillbirths } \begin{array}{r}(31-41 \\
\text { weeks of gestation) }\end{array}\end{array}$ & 5 & Intrapartum anoxia & Nil \\
\hline \multirow{5}{*}{$\begin{array}{l}\text { Livebirths (22-28 } \\
\text { weeks of gestation) }\end{array}$} & 5 & HMD & 4.5 \\
\hline & & HMD + pneumothorax & 5.5 \\
\hline & & HMD + pneumothorax & 11.5 \\
\hline & & $\begin{array}{l}\text { Intraventricular hemorrhage } \\
+ \text { septicemia }\end{array}$ & 31.0 \\
\hline & & Intraventricular hemorrhage & 95.0 \\
\hline \multirow{8}{*}{$\begin{array}{l}\text { Livebirths }(31-42 \\
\text { weeks of gestation) }\end{array}$} & 8 & HMD & 30.0 \\
\hline & & HMD & 32.5 \\
\hline & & $\begin{array}{l}\text { HMD, septicemia, intraven- } \\
\text { tricular hemorrhage }\end{array}$ & 52.0 \\
\hline & & $\begin{array}{l}\text { Intrapartum anoxia, subdural } \\
\text { hemorrhage }\end{array}$ & 3.3 \\
\hline & & Encephalocele & 17.0 \\
\hline & & Congenital heart disease & 48.0 \\
\hline & & $\begin{array}{l}\text { Intrapartum anoxia }+ \text { pneu- } \\
\text { monia }\end{array}$ & 8 days \\
\hline & & $\begin{array}{l}\text { Intrapartum anoxia }+ \text { pneu- } \\
\text { monia }\end{array}$ & 14 days \\
\hline
\end{tabular}

'HMD: hyaline membrane disease.
Table 2. Fatty acid chains on acetone-precipitated lecithin of alveolar wash (17 cases without hyaline membrane disease), expressed as mean percentages ${ }^{1}$

\begin{tabular}{|c|c|c|c|c|c|c|}
\hline \multirow[b]{3}{*}{ Fatty acid } & \multicolumn{6}{|c|}{ Mean \% } \\
\hline & \multicolumn{2}{|c|}{$22-28$ weeks } & \multicolumn{2}{|c|}{ 29-32 weeks } & \multicolumn{2}{|c|}{$37-42$ weeks } \\
\hline & $\begin{array}{c}\alpha- \\
\text { Chain }\end{array}$ & $\begin{array}{c}\beta- \\
\text { Chain }\end{array}$ & $\begin{array}{c}\alpha^{-} \\
\text {Chain }\end{array}$ & $\begin{array}{c}\beta- \\
\text { Chain }\end{array}$ & $\begin{array}{c}\alpha^{-} \\
\text {Chain }\end{array}$ & $\begin{array}{c}\beta- \\
\text { Chain }\end{array}$ \\
\hline Myristic, 14:0 & 5.8 & 7.0 & 1.2 & 6.5 & 5.6 & 9.2 \\
\hline Palmitic, 16:0 & 65.6 & 53.8 & 59.0 & 54.0 & 72.4 & 63.0 \\
\hline Palmitoleic, 16:1 & 9.2 & 4.6 & & 2.7 & 1.0 & 3.8 \\
\hline Stearic, 18:0 & 8.4 & 12.2 & 9.8 & 13.5 & 10.2 & 4.3 \\
\hline Oleic, 18:1 & 4.4 & 15.6 & 11.5 & 11.5 & 1.8 & 7.6 \\
\hline Linoleic, 18:2 & 0.5 & 0.6 & 5.5 & 2.3 & 2.6 & 3.5 \\
\hline Linolenic, 18:3 & 1.0 & 0.8 & 2.7 & 0.7 & 0.6 & 1.5 \\
\hline Arachidic, 20:0 & & 2.0 & 1.8 & 6.0 & 1.4 & 4.2 \\
\hline Arachidonic, 20:4 & 3.4 & & 5.2 & 1.8 & 2.0 & 0.3 \\
\hline Behenic, 22:0 & 1.2 & 3.4 & 3.3 & 0.2 & 1.3 & 1.6 \\
\hline Erucic, 22:1 & 0.5 & & & 0.8 & 1.1 & 1.0 \\
\hline$\%$ Saturated & 81.0 & 78.4 & 75.1 & 79.6 & 90.9 & 82.3 \\
\hline $\mathrm{P} / \mathrm{M}$ ratio & 11.3 & 7.7 & 49.2 & 8.2 & 12.9 & 6.8 \\
\hline $\mathrm{P} / \mathrm{S}$ ratio & 7.8 & 4.4 & 6.0 & 4.0 & 7.1 & 14.7 \\
\hline
\end{tabular}

' P/M ratio: palmitic to myristic acid ratio; $\mathrm{P} / \mathrm{S}$ ratio: palmitic to stearic acid ratio.

both $\alpha$ - and $\beta$-palmitic acid and total saturated fatty acids after 37 weeks of gestation (the range for palmitic acid was $22-76 \%$ before 32 weeks of gestation and $42-95 \%$ after 37 weeks). Individual amounts of myristic acid varied between $0 \%$ and $14 \%$ with no relationship to gestation as also reflected in the palmitic-myristic $(\mathrm{P} / \mathrm{M})$ ratio (Table 2$)$.

Fatty acids showing decreases during gestation were $\alpha$ - and $\beta$ oleic and $\beta$-stearic. The palmitic to stearic $(\mathrm{P} / \mathrm{S})$ ratio of the $\beta$ chain was higher after 37 weeks of gestation; there was little change in $\alpha$-chain $\mathrm{P} / \mathrm{S}$ ratios with gestation. Acetone-soluble lecithin showed similar variations to acetone-precipitated lecithin but with a slightly higher proportion of unsaturated fatty acids (data available on request).

\section{PHOSPHATIDYL DIMETHYL ETHANOLAMINE AND PHOSPHATIDYL ETHANOLAMINE}

These two phospholipids had similar fatty acid chains. Most extracts had a high proportion of long chain, unsaturated fatty acids which were not identified. The proportions of identified fatty acids on the acetone-precipitated PDME of the 17 nonHMD cases are shown in Table 3 .

The proportions of both $\alpha$ - and $\beta$-palmitic acid increased after 37 weeks of gestation (range 17-50\% before 32 weeks, 24-92\% after 37 weeks) but, on average, was not present in such large quantities as on the lecithin.

The highest individual amount of myristic acid was $26 \%$ but most extracts had much less than this (range 0-26\%). Variations in stearic and oleic acids were similar to those of the lecithin fraction, although the variation in the $\mathrm{P} / \mathrm{S}$ ratio was not so great. The proportion of saturated fatty acids (excluding unidentified long chain acids) was lower than on the lecithin fraction.

The acetone-soluble fraction contained very little PDME, PE, or sphingomyelin so no comparisons could be drawn with the acetone-precipitated fraction.

\section{HYALINE MEMBRANE DISEASE}

The results for the six infants who died of hyaline membrane disease are shown in Table 4. Palmitic acid was present in lower quantities on both acetone-precipitated and acetone-soluble lecithin. The $\mathrm{P} / \mathrm{S}$ ratio was also low. There was a higher percentage of unsaturated fatty acids and longer chain saturated fatty acids when compared with infants who did not have HMD. Higher 
concentrations of myristic acid were present in the acetonesoluble fraction. PDME was not present in any of the extracts.

When the (acetone-precipitated) lecithin results of the 13 liveborn babies were divided into HMD and non-HMD (7) cases, some interesting variations in palmitic acid were present (Fig. 3), with the main differences on the $\beta$-chain. Logarithmic transformation of the data and application of a Student t-test showed that the HMD group had a significantly lower proportion of $\beta$-lecithin palmitic acid $(P<0.05>0.02)$. Lecithin myristic acid showed little difference between the two groups.

\section{EFFECTS OF EXTRAUTERINE SURVIVAL}

In the group of non-HMD babies born before 28 weeks of gestation, five made no attempt at spontaneous respiration and two survived for 31 and $95 \mathrm{hr}$ before death (caused by intraventricular hemorrhage). These two babies (both female) had larger amounts of $\beta$-palmitic acid on both lecithin and PDME compared with the stillborn infants (Fig. 4). Two of the stillbirths

Table 3. Fatty acid chains on acetone-precipitated phosphatidyl dimethylethanolamine of alveolar wash expressed as mean percentages (17 cases without hyaline membrane disease)'

\begin{tabular}{|c|c|c|c|c|c|c|}
\hline \multirow[b]{3}{*}{ Fatty acid } & \multicolumn{6}{|c|}{ Mean \% } \\
\hline & \multicolumn{2}{|c|}{$22-28$ weeks } & \multicolumn{2}{|c|}{ 29-32 weeks } & \multicolumn{2}{|c|}{$37-42$ weeks } \\
\hline & $\begin{array}{c}\alpha- \\
\text { Chain } \\
\end{array}$ & $\begin{array}{c}\beta- \\
\text { Chain } \\
\end{array}$ & $\begin{array}{c}\alpha- \\
\text { Chain } \\
\end{array}$ & $\begin{array}{c}\beta- \\
\text { Chain } \\
\end{array}$ & $\begin{array}{c}\alpha- \\
\text { Chain } \\
\end{array}$ & $\begin{array}{c}\beta- \\
\text { Chain } \\
\end{array}$ \\
\hline Myristic, 14:() & 4.5 & 14.0 & 9.7 & 5.3 & 6.4 & 8.6 \\
\hline Palmitic, 16:0 & 32.3 & 33.2 & 33.7 & 34.7 & 61.6 & 41.8 \\
\hline Palmitoleic, 16:1 & 10.5 & 6.2 & 3.0 & 5.8 & & 9.3 \\
\hline Stcaric, 18:0 & 11.5 & 12.8 & 17.7 & 16.5 & 13.6 & 7.2 \\
\hline Olcic, 18:1 & 20.2 & 19.2 & 12.7 & 14.3 & 8.2 & 13.8 \\
\hline Linoleic, 18:2 & 12.0 & 3.0 & 1.0 & 10.2 & 3.6 & 5.3 \\
\hline Linolenic, 18:3 & 1.3 & 4.6 & 1.7 & 3.5 & 0.4 & 1.5 \\
\hline Arachidic, 20:0 & 0.5 & 2.4 & & 4.5 & 2.6 & 4.3 \\
\hline Arachidonic, 20:4 & 4.2 & 2.4 & 0.3 & 2.7 & 0.4 & 3.5 \\
\hline Bchenic, 22:0 & & 1.8 & 8.3 & 2.3 & & 0.5 \\
\hline Erucic, 22:1 & 2.3 & & 0.7 & 1.0 & 3.2 & 2.5 \\
\hline \% Saturated & 48.8 & 64.2 & 69.4 & 63.3 & 84.2 & 62.4 \\
\hline $\mathrm{P} / \mathrm{M}$ ratio & 7.2 & 2.4 & 3.5 & 6.5 & 9.6 & 4.9 \\
\hline $\mathrm{P} / \mathrm{S}$ ratio & 2.8 & 2.6 & 1.9 & 2.1 & 4.5 & 5.8 \\
\hline
\end{tabular}

$1 \mathrm{P} / \mathrm{M}$ ratio: palmitic to myristic acid ratio; $\mathrm{P} / \mathrm{S}$ ratio: palmitic to stearic acid ratio.

Table 4. Fatty acids on lecithin of alveolar wash expressed as mean percentages (six cases with hyaline membrane disease)'

\begin{tabular}{lrrrrr}
\hline & \multicolumn{2}{c}{ Surface-active fraction } & & \multicolumn{2}{c}{$\begin{array}{c}\text { Nonsurface-active } \\
\text { fraction }\end{array}$} \\
\cline { 2 - 3 } \cline { 5 - 6 } \multicolumn{1}{c}{ Fatty acids } & $\alpha$-Chain & $\beta$-Chain & & $\alpha$-Chain & $\beta$-Chain \\
\hline Myristic, 14:0 & 5.2 & 6.3 & & 13.6 & 17.2 \\
Palmitic, 16:0 & 52.2 & 37.3 & & 21.4 & 33.4 \\
Palmitoleic, 16:1 & 0.6 & 13.0 & & & 9.0 \\
Stearic, 18:0 & 14.0 & 14.7 & & 12.8 & 9.4 \\
Oleic, 18:1 & 6.4 & 10.2 & & 19.6 & 12.2 \\
Linoleic, 18:2 & 2.4 & 3.5 & & 5.2 & 5.8. \\
Linolenic, 18:3 & & 3.2 & & 2.6 & 0.2 \\
Arachidic, 20:0 & 2.0 & 4.8 & & 13.8 & 6.0 \\
Arachidonic, 20:4 & 7.0 & 7.0 & & 2.0 & 3.4 \\
Behenic, 22:0 & & & & 10.8 & 3.6 \\
Erucic, 22:1 & 0.8 & & & 10.6 \\
\% Saturated & 73.4 & 63.1 & & 61.6 & 66.0 \\
P/M ratio & 10.0 & 5.9 & & 1.6 & 1.9 \\
P/S ratio & 3.7 & 2.5 & & 1.7 & 3.6 \\
\hline
\end{tabular}

$1 \mathrm{P} / \mathrm{M}$ ratio: palmitic to myristic acid ratio; $\mathrm{P} / \mathrm{S}$ ratio: palmitic to stearic acid ratio.

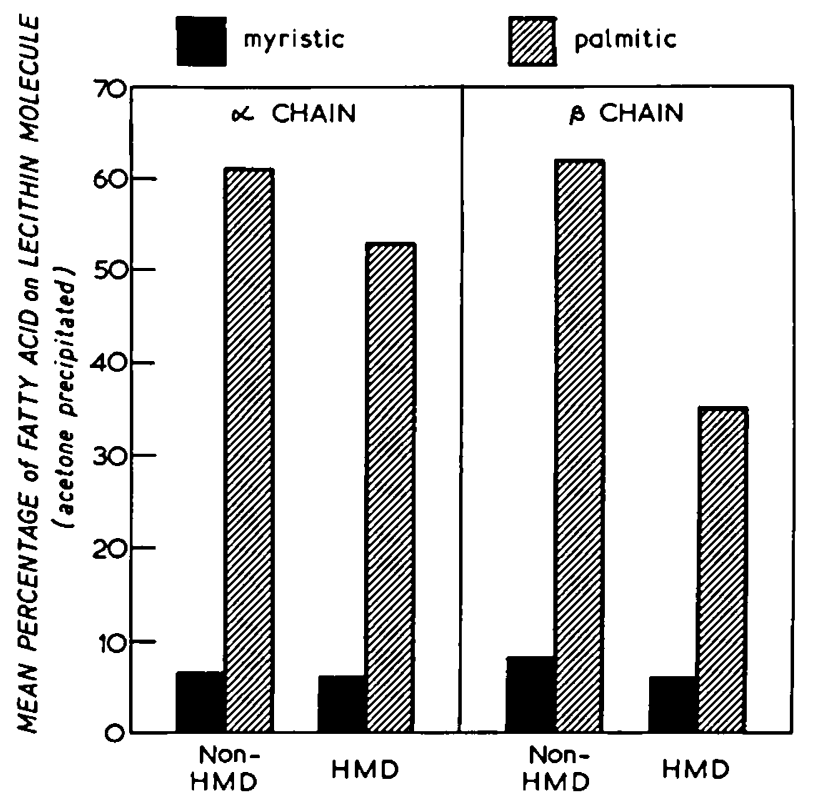

Fig. 3. Comparison between the major lecithin fatty acids in the lungs of non-hyaline membrane disease (non-HMD) and HMD babies.

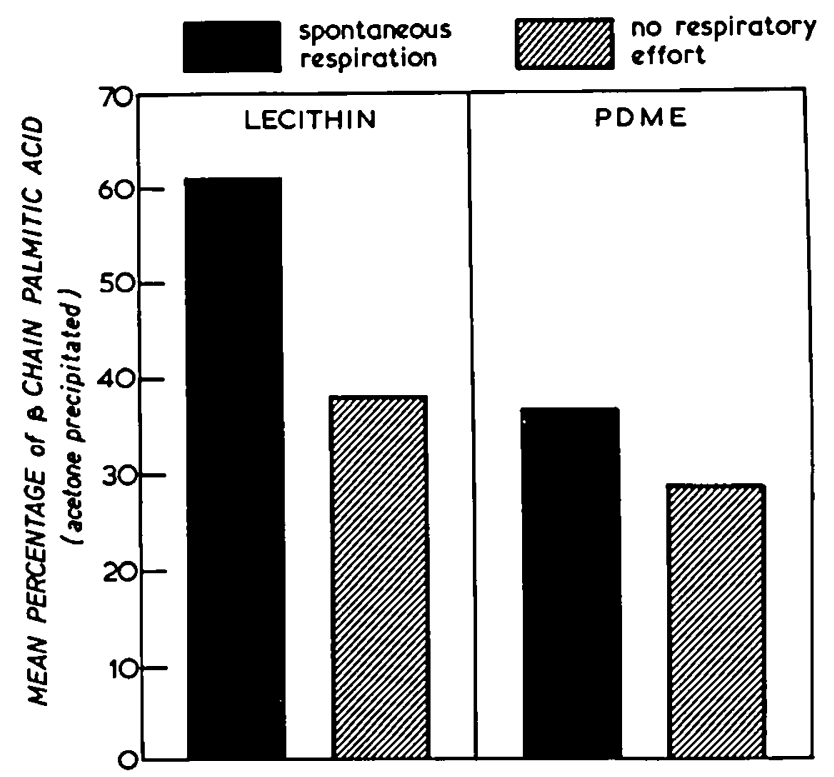

Fig. 4. Proportion of $\beta$-chain palmitic acid in lung phospholipids and its relationship to the respiratory status of the infants (non-hyaline membrane disease cases). PDME: phosphatidyl dimethylethanolamine.

were twins and their lecithin $\alpha$-chains had similar proportions of palmitic acid ( 74 and $76 \%$ ). On the lecithin $\beta$-chain the male twin had $13 \%$ less palmitic acid than the female twin. This male/ female difference was not present when the results of the whole group of 17 non-HMD cases were analyzed.

\section{DISCUSSION}

This study confirms the findings $(12,27)$ that PDME is not present in lung effluents of babies with RDS, and also that the level of lecithin palmitic acid is low in these infants. It does not confirm previous reports that PDME has a high proportion of $\beta$ myristic acid (13) nor that this high proportion of $\beta$-myristic acid is present on the lecithin of normally breathing babies (12).

Goerke and Clements (16) demonstrated that palmitoyl, myristoyl lecithin has very little surface activity so it is unlikely to be 
present in large quantities in the lungs of normally breathing infants. On the other hand, dipalmitoyl lecithin is extremely surface active $(19,23)$ and most probably plays a major role in preventing the lungs from collapse during respiration.

Phosphatidyl ethanolamine and sphingomyelin are also highly surface active (19) and increase in concentration in the lung during gestation (21). Therefore, dipalmitoyl lecithin probably does not act in isolation but in conjunction with other lecithins, phospholipids, and surfactant proteins.

Enzymic studies indicate that $97 \%$ of lecithin synthesis in the fetal lung is by pathway 1 and it is only the much quoted studies of Gluck and coworkers that have led to the speculation that pathway 2 is active at some stages of gestation and after the onset of respiration.

In this study the comparison between the fatty acids of PDME and lecithin shows that it is unlikely that lecithin is formed by the PDME route (pathway 2). The longer chain unsaturated acids present on the PDME were rarely seen on the lecithin and the PDME had fewer saturated acids than lecithin.

It has been suggested (22) that contamination of the snake venom or the chemicals used for extraction contributed to the apparently high proportions of myristic acid found in Gluck's studies. Contamination of laboratory reagents was a major problem in the early stages of our own study and it was eliminated by redistillation of the solvents used.

The increase in the $\mathrm{P} / \mathrm{S}$ ratio towards term is interesting since the measurement of this ratio has been suggested as a test on amniotic fluid for the presence of fetal pulmonary surfactant (2). It must be noted, however, that the array of fatty acids on all of the lung phospholipids shows considerable variation. Kerr and Helmuth (21) found high levels of stearic acid on the lung sphingomyelin of rhesus monkeys; this stearic acid would also be included in the amniotic fluid test. On this evidence the measurement of the L/S ratio of amniotic fluid is more likely to be accurate even though a false negative rate of $46 \%$ has been found with $\mathrm{L} / \mathrm{S}$ ratios below 2.0 (18).

The differences observed in the proportion of palmitic acid on the phospholipids of breathing compared with stillborn infants were also present in infants born at later gestations (12\% extra lecithin palmitic acid in the liveborn infants); these results were not included as some of the liveborn babies additionally developed pneumonia. A comparison of the stillbirths at all gestations with the five babies who breathed spontaneously and did not develop HMD or pneumonia shows that an $18 \%$ deficit of $\beta$ lecithin palmitic acid was present in stillborn babies. Previous studies have found up to a 30 -fold increase in surfactant production $1 \mathrm{hr}$ after the onset of respiration (12). These findings suggest that the onset of respiration not only stimulates the production of surfactant but also the synthesis of its most potent ingredient, dipalmitoyl lecithin.

\section{CONCLUSION}

It would seem from these studies that the key factor in the synthesis of surfactant phospholipids is the availability of palmitic acid and the ease of its incorporation into lecithin and PE. The synthetic pathways utilized are of secondary importance. Future research should be concerned with methods of promoting the production and availability of dipalmitoyl lecithin in the lungs of premature infants.

\section{REFERENCES AND NOTES}

1. Adams, F, H., Fujiwara, T., Emmanouilides, G., and Scudder, A.: Surface properties and lipids from lungs of infants with hyaline membrane disease. J. Pediat., 66: 357 (1965).
2. Alcindor, L. C., Bereziak, G., Vielh, J. P., and Gautray, J. P.: Le rapport de concentration acide palmitique sur stearique, indicateur de la maturite pulmonaire foctale. Clin. Chim. Acta, 50: 31 (1974).

3. Avery, M. E., and Mead, J.: Surface properties in relation to atelectasis and hyaline membrane disease. Amer. J. Dis. Child., 97: 517 (1959).

4. Bolande, R. P., and Klaus, M. H.: The morphological demonstration of an alveolar lining layer and its relationship to pulmonary surfactant. Amer. J. Pathol., 45: 449 (1964).

5. Boughton, K., Gandy, G., and Gairdner, D.: Hyaline membrane disease. II. Lung lecithin. Arch. Dis. Childhood, 45: 311 (1970).

6. Brown, E. S.: Isolation and assay of dipalmitoyl lecithin in lung extracts. Amer. J. Physiol., 207: 402 (1964).

7. Chamberlain, R., Chamberlain, G., Howlett, B., and Claireaux A.: British Births 1970. Vol 1. The first week of life, Chapt. 8, p. 235 (William Heinemann Medical Books Ltd., London, 1975).

8. Chida, N., Adams, F. H., Nozaki, M., and Norman, A.: Changes in lamb lung lipids during gestation. Proc. Soc. Exp. Biol., 122: 60 (1966).

9. Elsbach, P.: Phospholipid metabolism by phagocytic cells. Biochim. Biophys. Acta, 125: 510 (1966)

10. Farrell, P. M., and Avery, M. E.: Hyaline membrane disease. Amer. Rev. Resp. Dis., 111: 657 (1975).

11. Fujiwara, T., Hirono, H., and Arakawa, T.: Chemical identification of the surface active material isolated from calf lung. Tohuko J. Exp. Med., 85: 33 (1965).

12. Gluck, L., Kulovich, M. V., Eidelman, A. I., Cordero, L., and Khazin, A. F.: Biochemical development of surface activity in mammalian lung. IV. Pulmonary lecithin synthesis in the human fetus and newborn and etiology of the respiratory distress syndrome. Pediat. Res., 6: 81 (1972).

13. Gluck, L., Landowne, R. A., and Kulovich, M. V.: Biochemical development of surface activity in mammalian lung. III. Structural changes in lung lecithin during development of the rabbit fetus and newborn. Pediat. Res., 4: 352 (1970).

14. Gluck, L., and Sribney, M.: Synthesis of phospholipids in the lung of the developing rabbit fetus [Abstr.]. Physiologist, 8: 174 (1965).

15. Gluck, L., Sribney, M. and Kulovich, M. V.: The biochemical development of surface activity in mammalian lung. II. The biosynthesis of phospholipids in the lung of the developing rabbit fetus and newborn. Pediat. Res., 1: 247 (1967).

16. Georke, J., and Clements, J. A.: Relative stability of air/water films of palmitoyl myristoyl- and dipalmitoyl- phosphatidyl cholines at $37^{\circ} \mathrm{C}$ [Abstr.]. Physiologist, 16: 323 (1973).

17. Hallmann, M. and Raivio, K. 1.: Formation of disaturated lecithin through the lysolecithin pathway in the lung of the developing rabbit. Biol. Neonate, 27: 329 (1975).

18. Harvey, D. R., Parkinson, C. E., and Campbell, S.: Risk of respiratory distress syndrome. Lancet, $i: 42$ (1975).

19. Henderson, R. F., Waide, J. J., and Pfleger, R. C.: Methods for determining the fraction of pulmonary surfactant lipid removed from the lung of Beagle dogs by lavage. Arch. Int. Physiol. Biochem., 82: 259 (1974).

20. Kennedy, E. P., and Weiss, S. R. The function of cytidine coenzymes in the biosynthesis of phospholipids. J. Biol. Chem., 222: 193 (1956).

21. Kerr, G. R., and Helmuth, A. C.: Growth and development of the fetal rhesus monkey. V. Fatty acids of phospholipids in fetal lung. Biol. Neonate, 25: 10 (1975).

22. Kotas, R. V., Trainer, E. J., Mims, L. C., and Harlow, R. D.: Discrepancies between the Brockerhoff and Gluck methods of lung lecithin fatty acids analysis. Amer. Rev. Resp. Dis., 110: 669 (1974).

23. Kuenzig, M. C., Hamilton, R. W., and Peltier, L. F.: Dipalmitoyl lecithin: studies on surface properties. J. Appl. Physiol., 20: 779 (1965).

24. Morgan, T. E., Finley, T. N., and Fialkow, H.: Comparison of the composition and surface activity of "alveolar" and whole lung lipids in the dog. Biochim. Biophys. Acta, 106: 403 (1965).

25. Pattle, R. E., Claireaux, A. E., Davies, P. A., and Cameron, A. H. Inability to form a lung-lining film as a cause of respiratory distress syndrome in the newborn. Lancet, ii: 469 (1962).

26. Warren, C., Holton, J. B., and Allen, J. B.: Assessment of fetal lung maturity by estimation of amniotic fluid palmitic acid. Brit. Med. J., 1: 94 (1974).

27. Wu, P. Y. K., Borer, R. C., and Houchang, M.: Diagnosis of respiratory distress syndrome by the absence of phosphatidyl dimethylethanolamine (PDME) in tracheal effluents of low birth weight infants [Abstr.]. Pediat. Res., 5: 415 (1971).

28. We are most grateful to Dr. J. Wigglesworth of Hammersmith Hospital for providing us with a lung specimen for analysis. We had technical assistance from Miss P. Macrae and Mr. S. Rolph.

29. All solvents from B. D. H. Chemicals Ltd., Poole, Dorset, England.

30. Snake venom from Sigma London Chemical Co., Lid., Kingston-uponThames, Surrey, England.

31. Standards for gas chromatography from Supelco Inc., Bellafonte, Pa.

32. Requests for reprints should be addressed to: Miss C. E. Parkinson, Institute of Obstetrics and Gynaecology, Queen Charlotte's Hospital for Women, Goldhawk Rd., London W6 OXG (England).

33. Received for publication July 5, 1976.

34. Accepted for publication November 4, 1976. 